\title{
Computer Modeling of Carbohydrate Molecules
}

\author{
計算化学手段による糖鎖の分子モデリング
}

\author{
Yui, Toshifumi ${ }^{1}$; and Ogawa, Kozo ${ }^{2}$ \\ ${ }^{1}$ Department of Applied Chemistry, Faculty of Engineering, Miyazaki University, 889-2192, Nishi 1-1, \\ Gakuen-kibanadai, Miyazaki, Japan \\ ${ }^{2}$ International Polysaccharide Engineering, 591-8025, 130-42, Nagasone-cho, Sakai, Osaka, Japan \\ FAX: 81-985-58-7323, E-mail: tyui@cc.miyazaki-u.ac.jp
}

Key words: computer modeling, conformational analysis, molecular dynamics, molecular mechanics, carbohydrate parameters

\section{Abstract}

Although computer modeling of carbohydrates has had a long history, almost comparable to that of protein modeling, there are still some technical problems to be solved at present due to their complexity and versatility. Carbohydrates which comprise many polar functional groups, as represented by the hydroxyl group, exhibit significant flexibility in their three-dimensional structures. They change the electronic configurations depending on the three-dimensional configurations and conformations resulting in the specific stereochemical features, such as anomeric effect, exoanomeric effect, and gauche effect. In computer modeling, these stereochemical features of carbohydrates have required developments of the force fields and/or the parameter sets designed to reproduce them. The hydroxyl groups on a sugar residue form a hydrogen bond with water molecules and the solvation environment affects conformational behavior of the carbohydrate molecule. In fact, a stable water-mediated interresidue hydrogen bond has been detected in the molecular dynamics simulations for solvated carbohydrate molecules. Since carbohydrate molecules readily exhibit various conformations arising from the intrinsic flexibility of glycosidic linkages, conformational analysis was required to systematically explore possible conformations and evaluate their steric energies. On the other hand, carbohydrate molecules often generate a large and complex conformational space derived from diversities of sugar residues and substitutents, and formation of branching structures. Several algorithms intended for an effective search for such a conformational space have been examined.
要 約

糖質分子を対象としたコンピュータによる分子モデリン グはタンパク質に匹敵する長い歴史を持つが、現在でも糖質 分子の複雑さと多様さゆえに幾つかの解決すべき問題点が残 されている。糖質分子は水酸基で代表される極性官能基を多 く持ち、立体構造の柔軟性が高く、さらにアノメリック効果、 エキソアノメリック効果、ゴーシュ効果のような立体配置 · 立体配座に依存する電子構造変化が生じる。このような糖質 分子の立体化学的特性を再現するために糖質専用の分子力場 が、あるいは汎用力場に対しては糖質パラメーターが開発さ れた。糖残基上の水酸基は水分子と水素結合を形成するため、 水和環境が糖質分子の立体構造に影響すると推定される。実 際、溶媒和分子動力学計算において水分子が介在する恒常的 な残基間水素結合が観察された。また、グリコシド結合回転 に由来する柔軟性により糖質分子は水溶液中で容易に配座変 換を生じるため、立体配座解析により可能な立体配座を網羅 的に生成し、それらの立体エネルギーを評価することが必要 とされた。一方、糖質分子は構成残基や置換基の多様性、お よび分岐構造の形成等により複雑で大きな立体配座空間を生 じる。その様な立体配座空間を効率良く探索するための探索 アルゴリズムが提案された。

\section{A. 序 論}

分子モデリングとは分子の立体構造 (時には電子構造を含

In general, molecular modeling predicts the threedimensional structures (electronic structure, in this case) of a given molecule and their energies, based on the theoretical calculations with a computer. Molecular modeling techniques includes visualization and in-silico construction/conversion of molecules using molecular graphics tools, and a molecular
む) とエネルギー状態を予測する手段であり、通常、コンピュー 夕による理論計算に基づいて実行される。分子モデリングに は分子グラフィックスを通した分子の可視化と分子構築・変 換操作の他、分子動力学計算によって分子または分子集合体 
dynamics simulation which traces dynamic behavior of molecular assembly as well as an isolated molecular system. Recently, the molecular modeling study for biopolymers has been increasing in its significance as it is combined with bioinfomatics. Carbohydrate modeling study was at first driven by scientific interest to study stereochemical features of carbohydrate systems. As increasing in our understanding of their biological and physiological functions, the modeling technique has been extended to more complicated systems such as glycoconjugates and carbohydrate-protein complexes that involve these higher functions.

Comparing carbohydrates with proteins and polypeptides in terms of the three-dimensional structure, a clear structure classification, such as secondary structures and motifs, has not yet been suggested for carbohydrates (1). Although the polysaccharide having a regular repeating unit may conform with a regular helical structure in the crystal structure, the resulting helical forms are widely diverse depending on the types of constituent residue and of backbone glycosidic linkage structure, and they sometimes construct multiple helices $(2,3)$. This is obviously a different situation from polypeptides which, consisting of a unique peptide linkage, exhibit limited helical forms such as $\alpha$-helix and $\beta$-strand. Furthermore, as for the branched oligosaccharides and polysaccharides with a more complicated chemical structure, it seems that no one has attempted to develop a systematic understanding between the branching scheme and the three-dimensional structure. Since the free hydroxyl groups present on sugar residue can function as both hydrogen donor and acceptor on forming a hydrogen bond, an intensive hydrogen bonding network is likely to be formed in a sugar crystal structure (4). In an aqueous environment, hydroxyl groups involve hydrogen bonds with the surrounding water molecules and this causes structuring waters. Such interactions with water molecules are a significant factor in defining the three-dimensional structure of carbohydrates (5-7). In this respect of hydrogen bonding formation, however, polypeptide exhibits a much simpler scheme; a single type of hydrogen bond of $-\mathrm{NH}---\mathrm{O}=\mathrm{C}-$ on a peptide linkage. It should also be noted that the oligosaccharides consisting of more than four to five sugar units may exhibit multiple conformational states in solution due to the inherent flexibility of the glycosidic linkages, and that the solution structure data obtained, for example, from NMR experiment represents an ensemble average of multiple conformations. The proposed threedimensional structure, therefore, based on the hydrogenhydrogen distances of NOE measurement could have no physical sense (8). The structural flexibility often inhibits the oligosaccharides more than a tetrasaccharide from crystallization into a single crystal for X-ray diffraction measurement, resulting in a limited number of crystal data.
の動的な挙動を追跡する分子シミュレーションも含まれる。 近年、生体高分子を対象とした分子モデリングはバイオイン フォマティックス技術との融合により、ますます、その重要 性が増しつつある。糖質分子を対象とした分子モデリングは、 当初、基礎研究の立場から糖質分子の立体化学研究を契機と し、糖鎖の生理学的重要性が明らかになるに従って、複合糖 質糖鎖や糖鎖 - タンパク質複合体等、より高次の生命現象に かかわる糖質分子システムへと研究対象が展開されてきた。

立体構造の視点から糖質分子をポリペプチド鎖あるいは タンパク質と比較した場合、まず糖質分子の立体構造は明確 な二次構造や立体構造モチーフに分類できないことが举げら れる $(1)$ 。一定の繰り返し単位構造を持つ多糖類分子鎖は結晶 状態で固有の規則性らせん構造を形成するが、それらのらせ ん構造は主鎖を構成する残基の種類やグリコシド結合様式に よって様々な形態を示し、さらに一部の多糖類は自発的に二

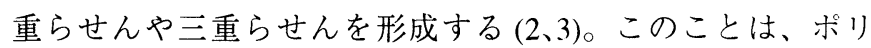
ペプチド鎖がペプチド結合という共通の骨格構造を持ち $\alpha$ へ リックスや $\beta$ ストランドのような限られた二次構造に分類さ れる状況とは明らかに異なる。当然、より複雑な化学構造を 持つ複合糖質糖鎖や分岐状多糖類に関して分岐構造と立体構 造形成挙動の関係を体系化する試みは現在まで報告されてい ない。糖残基上の遊離水酸基は水分子と同様に水素結合の水 素供与体および受容体として機能するため、結晶構造中で緊 密な水素結合ネットワークが形成される(4)。また、水酸基は 水溶液中に打いては糖残基 - 水分子間の水素結合形成や溶質 分子周囲の水分子の構造化に影響するとともに、これら水分 子との相互作用は糖質分子の立体構造を支配する重要な因子 となっている (5-7)。水素結合形成という点に関しても、ポリ ペプチド分子鎖ではペプチド結合間の $\mathrm{N}-\mathrm{H}---\mathrm{O}=\mathrm{C}$ という 1 種 類の水素結合パターンしか形成されないことから、糖質分子 と比べてはるかに単純な状況である。4〜 5 残基以上で構成さ れる糖質分子はグリコシド結合の回転に由来する分子構造の 柔軟性により溶液中で一定の立体構造をとらず、NMR 等の溶 液構造情報を与える測定結果は複数の立体配座のアンサンブ ル平均を反映する。このような場合、NOE ピーク強度から計 算される水素原子間距離をもとに提案された糖鎖分子の立体 配座は物理的に意味を持たない構造に相当することが指摘さ れている (8)。さらに、糖質分子の柔軟性により四糖以上の糖 質分子は結晶化が妨げられ、 $\mathrm{X}$ 線結晶構造解析デー夕数の増 加を阻む主因となっている。 
Therefore, molecular modeling techniques are clearly essential for the three-dimensional structure studies of carbohydrate molecules. The modeling technique with high precision is not only applicable to complement the experimental data but also could predict a reliable structure without referring to the experimental data This review will first discuss the stereochemical features of carbohydrates in the light of molecular modeling and then introduce the representative results of molecular mechanics (MM) and molecular dynamics (MD) studies, some of which have been reported by the authors. The books recommended to be read are listed in Reference 9 for further understanding of the theoretical background of the molecular modeling, i.e. computational chemistry, MM, and MD.

\section{B. Force Field and Parameters for Carbohydrate System}

The anomeric effect is the well-known, stereochemical feature for carbohydrate molecules and the exo-anomeirc effect should be mentioned herein as the factor that defines the three-dimensional structures of di-, oligo-, and polysaccharides. The anomeric effect stabilizes an axial substituent whose configuration would otherwise not be favored stereochemically. The effect is further enhanced by the presence of the electronegative substituent on the anomeric carbon. The exo-anomeric effect, on the other hand, tends to stabilize the torsion angles of a C1-O bond, namely $\Phi$, with a "gauche" orientation rather than a "trans" one, although the latter is preferred in ordinary stereochemical conditions. The anomeric and exo-anomeric effects were discussed in detail by the review of Tvaroska and Bleha, which includes the interpretations based on the theoretical calculations (10). Tvaroska and Carver reported the precise, ab initio molecular orbital calculations for the tetrahydropyran (THP) derivatives, as a model compound of sugar residue, and the quantitative evaluations of the anomeric and exo-anomeirc effects exhibited by the model compounds $(11,12)$.

In order to reproduce these stereochemical behaviors, the force fields and parameter sets which had been intended for the carbohydrate modeling were proposed. Among them, $\operatorname{HSEA}(13,14)$ and PFOS $(15,16)$ are classified into the rigidresidue-based force field, which evaluates steric energy for a given residue geometry. As for the force fields involving structure optimizations $(*)$, in order to apply MM3 (17) of the representative, general purpose force field and, AMBER (18) and CHARM (19) - both of which were developed for the protein and polynucleotide simulations - to carbohydrate modeling, the modified parameters have been proposed for each respective force fields. The carbohydrate parameters for MM3 were presented by the MM3 developers, Allinger and his coworkers (20), and several groups other than the developers have been engaged in developing the parameters
従って、糖質分子の立体構造研究において分子モデリング は不可欠な手段となり、注意深く実行された計算結果は実験 データを裏付けるだけでなく、単独でも信頼性の高い予測モ デルを提供する。本レビューでは、分子モデリングの視点か ら糖質分子の立体化学的特性について解説し、さらに筆者に よる計算例を含めた分子力学法 (MM) や分子動力学法 (MD) 計 算による研究成果を紹介する。分子モデリング方法の背景と なる計算化学一般、および MM MDについてはこれらに関 する成書を参照していただきたい (9)。

B. 糖質分子カ場とパラメーターセット

糖質分子の立体化学的特徵として“アノメリック効果” が良く知られているが、さらに二糖、オリゴ糖および多糖類 分子の立体構造に大きく影響する因子として、“エキソア， メリック効果”が挙げられる。アノメリック効果とはアノメ リック炭素に電気陰性置換基が結合している場合、通常立体 化学的に不利なアキシャル配置に異常な安定化効果が生じる 現象である。一方、エキソアノメリック効果とは $\mathrm{Cl}-\mathrm{O}$ 結合回 転角 $(\Phi)$ に対して、立体化学的に好まれる“trans”配座より も “gauche”配座を安定化させる効果である。理論計算によ る解釈を含めたアノメリック効果とエキソアノメリック効果 に関する詳細な総説がTvaroska と Blehaによって発表された (10)。さらに、Tvaroska と Carver はテトラハイドロピラン (THP) 誘導体分子を糖残基のモデル分子として、これらが示すア， メリック効果、エキソアノメリック効果について溶媒効果を 含めた厳密な $a b$ inito 分子軌道計算法を実行し、それらの効果 に対する定量的評価を報告した $(11 、 12)$ 。

以上で述べた立体化学的特性の再現を目的として糖質分 子固有の力場やパラメーターセットが提案されている。その 中でもHSEA(13、14) およびPFOS $(15 、 16)$ は与えられた分子構 造をもとに立体エネルギーを計算する固定残基力場として分 類される。分子立体構造の構造最適化 (注 1) を前提とした力 場の場合、代表的な汎用力場である MM3 力場 (17) および夕ン パク質や核酸の分子シミュレーションを目的として開発され たAMBER (18)やCHARM (19) 力場に対して糖質モデリング への適用を目的とした修正パラメーターが提案された。MM3 開発者である Allinger らによって MM3 糖質パラメーターが発 表されたが(20)、AMBERやCHARM力場については開発者 とは異なる幾つかの研究グループによって糖質パラメーター 
for AMBER and CHARM. The GLYCAM parameter set first proposed by Woods in 1993 for AMBER (21) has continuously been improved since then, to provide a better prediction on the solution structures of carbohydrates $(7,22$, 23). The parameter set was most focused on reproduction of nonbonding interactions so that the different sets of atomic charges derived from electrostatic potential calculations were defined for individual sugar residues. The three parameter sets for CHARM were proposed by Brady and his coworkers (HGFB (24), Palma et al.(25),CSFF (26)). In order to compare the performance of these parameter sets, the three series of solution simulations for the two disaccharides with either $\alpha-1$ $\rightarrow 3$ or $\alpha-1 \rightarrow 6$ linkage (methyl- $\alpha$-D-matoside or methyl$\alpha$-D-isomaltosie) as a test compound were carried out using the AMBER-GLYCAM, and the CHARM-HGFB and -CSFF sets (27). In the study, the AMBER-GLYCAM calculations best reproduced the solution structures with respect to the glycosidic linkage conformations and the orientations of the hydroxylmethyl groups. On the other hand, it was observed that the CHARM- HGFB calculations effectively reproduced the structured water-solute systems and predicted the selfdiffusion coefficients which were in better agreement with the experimental values than those predicted by the two other parameter sets, while it failed to predict appropriately the hydroxymethyl orientations.

A complete review of the force fields and parameter sets for carbohydrate molecules, including the parameter sets other than those discussed here, was reported by Woods (28). Pérez et al. carried out the comparative optimizations based on the same protocol for the seven test carbohydrate molecules using the 20 force fields and/or parameter sets. The results were studied by chemometric analysis, or principal component analysis (29).

(*) A structure optimization is the computational process that adjusts the three-dimensional structure of a molecular system so as to minimize its steric energy. The mathematical algorithms installed in the current computational chemistry softwares can only explore the neighboring minimum structure from the starting one. In the case of a biopolymer having a large internal flexibility, its conformational space should consist of the multiple minima, with the result that a single optimization run merely reaches one of the minima, and may rarely reach the global minimum.

\section{Ramachandran Map for Disaccharide Modeling}

The most important structural parameters to define the three-dimensional shape of carbohydrate systems are the rotation angles (the torsion or dihedral angles) of the glycosidic linkages connecting sugar residues. As shown in Fig. 1 (a), the rotation angles are termed $\Phi-\Psi$, which are defined by the two sets of definitions; the hydrogen-based
の開発が試みられた。なかでも、1993 年にWoodsによって公 開された AMBER 力場対応の GLYCAM パラメーター (21) は、 糖質分子溶液構造の予測精度を向上するために公開後も改良 が重ねられてきた $(7 、 22 、 23) 。$ GLYCAM パラメーターでは非 結合相互作用の再現性を重視し、静電ポテンシャルに基づい た原子点電荷を糖残基ごとに定義している。同様にCHARM 力場に対応する糖質分パラメーターも Brady らによって提案さ れた (HGFB (24)、Palma et al. (25)、CSFF(26))。これらの糖質 パラメーターの性能を比較するために、 $\alpha-(1 \rightarrow 4)$ および $(1 \rightarrow$ 6) 結合の 2 種のグルコース二糖分子 (メチル $-\alpha-\mathrm{D}-$ - マルトシド、 メチル - $\alpha$-D-イソマルトシド)をテスト分子として AMBERGLYCAM パラメーターおよび 2 種の CHARM パラメーターで ある HGFB と CSFFを用いた溶媒和 MD 学計算が実施された (27)。その結果、AMBER-GLYCAM 計算はグリコシド結合配 座やメチル水酸基の配向に関する実験結果を最も良く再現し た。一方、CHARM-HGFB 計算は糖質分子周囲の水分子が示 す構造化の再現に有効であり、糖質分子の水溶液中における 拡散挙動パラメーターについて他の 2 法と比べて実験值と良 く一致する計算值を与えたが、メチル水酸基配向については 適切な結果が得られなかった。

ここで紹介したもの以外の糖質パラメーターや各種の分 子力場については Woodsによる総説で詳細に解説されている (28)。Pérez らは、7 種のテスト糖質分子を対象として 20 種類 の分子力場拉よびパラメーターを用いた最適化計算を実行し、 ケモメトリックス手法による計算結果の主成分分析について 報告した (29)。

( 注 1) 構造最適化とは分子の立体エネルギーが最安定值と なるように立体構造を調節するプロセスである。ただし、既 存の計算化学プログラムに実装されている構造最適化アルゴ リズムは、与えられた初期構造から最も近傍のエネルギー極 小点の構造を探索する。一般に生体分子のように内部自由度 の大きな分子システムは、複数の極小点構造を持つため、1 回 の最適化計算で得られる構造は極小点構造のひとつにすぎず、 それが最安定配座に相当する保証は得られない。

C. Ramachandran マップによる二糖分子モデリング

糖鎖分子全体の分子形態を決定する最も重要なパラメー ターは糖残基を結合するグリコシド結合の回転角 (二面体角ま たは、ねじれ角)である。図1 (a) で示されるようにグリコシ ド結合の回転角は一般に $\Phi 、 \Psi$ という名称で呼ばれ次の 2 種 類の定義が使用される。一つは水素原子を用いた、 $\Phi=\mathrm{H} 1$ - 

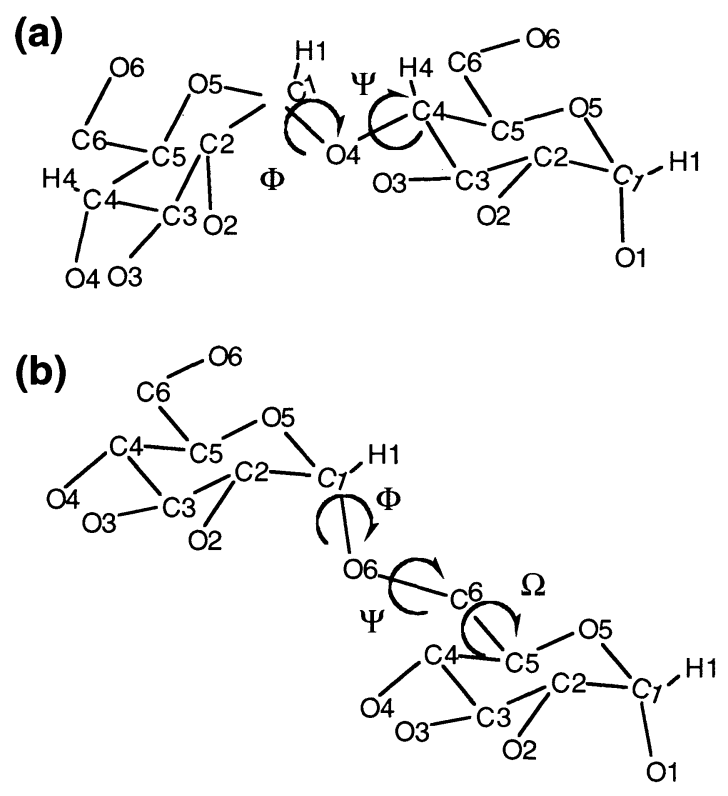

Fig. 1. Atom labeling and torsion angles of interest for (a) $\alpha$-maltose and (b) $\alpha$-isomaltose.

atom sequence, $\Phi=\mathrm{H} 1-\mathrm{C} 1-\mathrm{Ox}-\mathrm{Cx}, \Psi=\mathrm{C} 1-\mathrm{Ox}-\mathrm{Cx}-\mathrm{Hx}$, or the $\mathrm{O} 5$ atom-based one, $\Phi=\mathrm{O} 5-\mathrm{C} 1-\mathrm{Ox}-\mathrm{Cx}, \Psi=\mathrm{C} 1-\mathrm{Ox}-\mathrm{Cx}-$ $\mathrm{Cx}+1$, where $\mathrm{x}=1,2, \ldots 4$. The conformation of a $1 \rightarrow 6$ linked disaccharide given in Fig. 1 (b) involves an additional rotation angle about $\mathrm{C} 5-\mathrm{O} 6$ bond $(\Omega=\mathrm{O} 5-\mathrm{C} 5-\mathrm{C} 6-\mathrm{O} 6)$ and is defined by the three rotational parameters.

The Ramachandran map that we have once met in any biochemistry text book represents the results of conformational analysis (*) of a dipeptide unit. In the $1960 \mathrm{~s}$, Rao et al., who belonged to the Ramachandran's group, reported the Ramachandran maps for a series of different glucose dimers (30). They correspond to the steric energy surfaces with respect to the $\Phi-\Psi$ variations and are called the $\Phi-\Psi$ energy map. The limitations of the programming technique and the hardware in those days allowed the energy maps to be of rather qualitative or semi-quantitative evaluation, which only calculated the nonbonded van der Waals and hydrogen bond interactions based on rigid residue geometry. Afterwards, the "relaxed-residue" energy maps were reported for the same glucose dimer series where complete optimization of the residue geometry was introduced with respect to the MM3 force field $(31,32)(\dagger)$. Figure 2 depicts the MM3 generated relaxed-residue energy map of $\alpha$-maltose. In comparison with the "rigid-residue" energy maps, the energy minima displayed a more distinct, concave shape and the saddle points appeared between the potential minimum wells which revealed a conformational transition pass. It was also found in each energy surface that the low energy valley around $\Phi=60^{\circ}$ $-80^{\circ}$ ran along the $\Psi$ dimension, probably resulting from the exo-anomeric effect. The MM3 generated, $\Phi-\Psi-\Omega$ energy maps for both $\beta$-isomaltose and $\beta$-gentiobiose of the $1 \rightarrow 6$
C1-Ox-Cx、 $\Psi=\mathrm{C} 1-\mathrm{Ox}-\mathrm{Cx}-\mathrm{Hx} 、$ もう一つは 05 原子を含めた、 $\Phi=$ O5-C1-Ox-Cx、 $\Psi=\mathrm{C} 1-\mathrm{Ox}-\mathrm{Cx}-\mathrm{Cx}+1(\mathrm{x}=1,2, \cdots 4)$ の原子配 列による定義である。ただし、図 1 (b) に示す1-6 結合につい ては、C5-C6 結合回転に関する定義 ( $\Omega=$ O5-C5-C6-O6) が追 加され、この結合を持つ二糖分子の分子形態は三つの結合回 転角によって決定される。

生化学の教科書等で見かける Ramachandranマップは二量 体アミノ酸の立体配座解析 (注 1) の結果を表現したものであ る。60 年代に Ramachandran と同じグループであるRaoらに より一連のグルコース二糖分子に対する最初の Ramachandran マップが報告された (30)。これらは $\Phi$ - $\Psi$ 值変化に対する立体 エネルギー変化曲面に相当し、 $\Phi$ - $\Psi$ エネルギーマップと呼ば れる。当時のプログラミング技術とハードウエア能力の制限 からグリコシド結合角および糖残基の立体構造を固定し、主 に van der Waals 相互作用と水素結合エネルギーのみ計算する どちらかといえば定性的或いは半定量的な評価であった。そ の後、MM3 力場 (17) を用いて残基立体構造の構造最適化を導 入したグルコース二糖分子の “緩和残基”エネルギーマッ プが報告された $(31$ 、32)(注 2)。図 2 に $\alpha$-マルトースの MM3 緩和残基エネルギーマップを示す。“固定残基” エネルギー マップと比べてエネルギー極小点がより明確となり、各極小 点を含むポテンシャル井戸を結ぶ鞍部も確認された結果、配 座変換経路が明らかになった。また、 $\Phi$ 值 $60^{\circ} \sim 80^{\circ}$ 付近に エキソアノメリック効果によると推定される低エネルギーの 谷間が $\Psi$ 軸そって現れた。三次元ポテンシャル曲面を評価す るため膨大な計算量が要求される、 $1 \rightarrow 6$ 結合二糖分子 $\beta$ - イ 


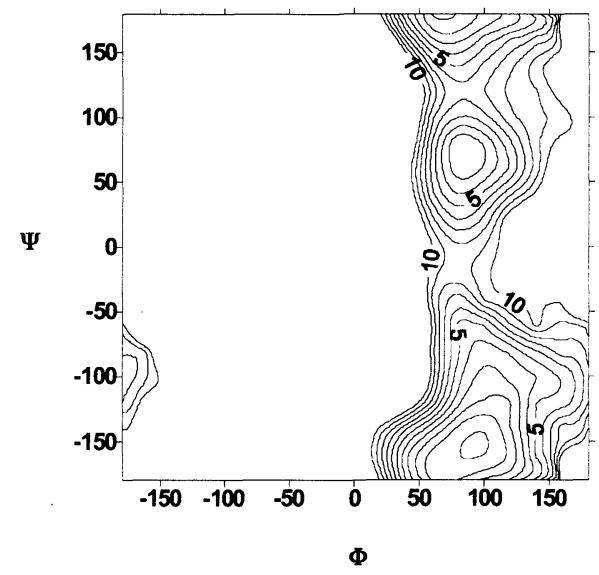

Fig. 2. MM3 generated "relaxed residue" energy map for $\alpha$-maltose with respect to the $\Phi-\Psi$ torsion angles. Counter lines are drawn in $1 \mathrm{kcal} / \mathrm{mol}$ increments above the global minimum.

linked disaccharides, which required an enormous amount of calculations to obtain the three-dimensional surfaces, were also presented, where the low energy spaces were found around $\Omega= \pm 60^{\circ}, 180^{\circ}(33)$. It was found that the principal features of the energy map of $\alpha$-maltose in Fig. 2 were similar to those of $\alpha 1 \rightarrow 2$ and $\alpha 1 \rightarrow 3$ linked dimers, i.e. kojibiose and nigerose, respectively, all having the common geometry of the "axial-equatorial" configuration in the glycosidic linkage (32). This had been already pointed out by the previous rigid-residue energy map calculations $(30,34)$. Similarly, the relaxed-residue energy maps of sophorose $(\beta 1 \rightarrow 2)$, laminarabiose $(\beta 1 \rightarrow 3)$, and cellobiose $(\beta 1 \rightarrow 4)$, each having the "equatorial-equatorial" linkage configuration, resembled each other (31). In addition, it was shown in the same MM3 calculations for the three type of mannobioses of either $\alpha 1$ $\rightarrow 2, \alpha 1 \rightarrow 3$, or $\alpha 1 \rightarrow 6$ linkage $(35,36)$ and chitobiose (37) that the resulting potential energy surfaces were similar to those of the corresponding glucose counterparts. These results described above, therefore, suggest that the stereochemistry of a disaccharide unit can be primarily characterized by the type of linkage configuration (34).

The glycosidic linkages of sucrose and trehalose involve the glycosidic oxygen between a pair of anomeric carbons facing each other and this type of linkage is known to exhibit the "over-lapping exo-anomeric" effect. The $\Phi-\Psi$ conformation observed in the sucrose crystal structure was found at the outside of the low energy region of the MM3 energy map and it was not confirmed to be a minimum until a more rigorous energy map was obtained by using the $a b$ inito molecular orbital method (38). This, therefore, indicated that the MM3 force field failed to predict the stable $\Phi-\Psi$ conformation for this type of disaccharide system. The problem arising at the sucrose modeling provides a typical example that one must always consider the applicability of the force field and parameters whenever using a molecular
ソマルトースと $\beta$ - ゲンチオビオースの MM 3 - $\Psi-\Omega$ エ ルギーマップ計算も報告され、 $\Omega= \pm 60^{\circ} 、 180^{\circ}$ の周辺で $\Phi$ - $\Psi$ 安定配座空間が確認された (33)。図 2 の $\alpha$-マルトース エネルギーマップの形状はグリコシド結合の幾何構造が $\alpha$ - マ ルトースと同じ “axial-equatorial” 構造となる $\alpha 1 \rightarrow 2$ と $\alpha 1$ $\rightarrow 3$ 結合二糖分子、すなわちコージビオースとニゲロースが 示すエネルギーマップの形状と基本的な特徴においてよく似 ていた (32)。同様な傾向は既に初期の固定残基による $\Phi-\Psi$ エネルギーマップ計算において指摘されていた $(30 、 34) 。$ 同様 に“equatorial-equatorial” 構造を持つソフォロース $(\beta 1 \rightarrow 2)$ 、 ラミナラビオース $(\beta 1 \rightarrow 3)$ およびセロビオース $(\beta 1 \rightarrow 4)$ の MM3 計算も互いによく似たエネルギー曲面を与えた $(31)$ 。ま た、 $\alpha 1 \rightarrow 2 、 \alpha 1 \rightarrow 3 、$ るいは $\alpha 1 \rightarrow 6$ 結合による3 種のマ ンノビオース $(35,36)$ やキトビオース (37) も、それぞれ、対応 するグルコース二糖分子と類似したエネルギーマップを与え ることも報告された。以上のことから、二糖分子の立体化学 はグリコシド結合の幾何構造によって基本的に決定されるこ とが明らかになった (34)。

ショ糖やトレハロースのようにグリコシド酸素を間にア ノメリック炭素が相対する構造を持つ二糖分子については “オーバーラッピングエキソアノメリック効果”と呼ばれる 現象が確認されている。ショ糖結晶構造より得られた $\Phi-\Psi$ 配 座はMM3 $\Phi-\Psi$ エネル゙ーマップ上では安定配座領域外に相 当し、 $a b$ inito 分子軌道計算法によって得られたより厳密な工 ネルギーマップからようやく極小点配座であることが確認さ れた (38)。従って、MM3 力場はこのような二糖分子の安定配 座を予測する能力がないと考えられた。このショ糖分子モデ リングの事例は分子力学を利用する場合、常にその力場やパ ラメーターの適用範囲に対する配慮が必要であることを示す 
mechanics technique.

While the "relaxed-residue" $\Phi-\Psi$ potential energy surface shown in Fig. 2 represents the lowest steric energy at each $\Phi-\Psi$ grid point of a disaccharide unit, a more realistic distribution of $\Phi-\Psi$ conformers should be described by the free energy surface including conformational entropy contribution. In addition, when modeling a carbohydrate solution, the solvent effect must be introduced into the free energy. The free energy surface including these two factors thus can be obtained by performing MD calculation in solution system. Brady et al. adopted the "umbrella sampling" technique - the modified MD method allowing effective search for conformational space - to the energy map calculations of maltose (39) and $\alpha 1 \rightarrow 4$ linked xylobiose (40) and proposed the free energy (namely, potential mean force, PMF) surfaces. When compared with the ordinary steric energy map, it was observed in the PMF map that the energy barrier between the two adjacent potential wells were lowered (39) and the position of the lowest steric energy moved from that of the previous map as a result of the formation of a constant, water-mediated hydrogen bond between the residues (40). A more significant change in the potential energy surface was reported by the PMF study of neocarrabiose, a repeating unit of $\beta$-carrageenan (Scheme 1). Figure 3 compares (a) the steric energy (41) and (b) solvated PMF (42) maps of neocarrabiose. The "a" minimum corresponding to the lowest minimum in the steric energy surface of Fig. 3 (a) became the highest one in the PMF surface of Fig. 3 (b) and, conversely, the "e", the highest one, in Fig. 3 (a), the lowest "w" in Fig.3 (a). These variations in the potential surfaces may be caused by the solvation effect involved in the PMF calculation. In fact, the water-mediated interresidue hydrogen bond was detected in the minimum conformations as was found in the xylobiose case. It seems to be interesting that the $\Phi-\Psi$ conformation corresponding to the crystal structure (the " 1 " minimum in Fig.3 (a)) appeared near the lowest minimum in the PMF map. On the contrary, no distinct solvation effect was detected in the PMF map of carrabiose, another repeating unit of carrageenan (43).

(*) A conformational analysis is the technique that establishes the topology consisting of locations of the minima and their steric energies with respect to important structural parameters (the potential energy surface) in order to evaluate and realize conformational space of an objective molecule.

$(\dagger)$ In relaxed-residue energy map calculations, the
好例であろう。

図 2 の緩和残基 $\Phi$ - $\Psi$ エネルギーマップは分子の立体工ネ ルギーに由来するポテンシャル曲面に相当するが、実際の立 体配座の分布は配座エントロピーを含めた自由エネルギー曲 面で評価されるべきである。また、糖鎖分子の溶媒構造をモ デリングする場合、溶媒による影響も無視できない。以上の 2つの因子を含めたポテンシャル曲面は溶媒分子を含めた MD 計算よって得られる。Brady らは配座空間を効率良く探索する MD 計算法の一種である “アンブレラサンプリング” 法をマ ルトース (39) と $\alpha 1 \rightarrow 4$ 結合キシロビオース (40)のエネルギー マップ計算に応用し、高エネルギー領域や配座遷移領域を含 めた自由エネルギー(または、Potential Mean Force、PMF) 曲 面を求めた。従来の立体エネルギーマップと比較したところ、 隣接する2 所の極小点間のエネルギー障壁が低下し (39)、水 分子が糖残基間で恒常的な水素結合を形成した結果、PMFマッ プ上で最安定極小点が移動する現象が確認された (40)。さらに 大幅なエネルギー曲面の変化が $\beta$ - カラギーナンの構成二糖に 相当するネオカラビオース (スキーム 1)の PMF 計算において 報告された。図3にネオカラビオースの (a) 立体エネルギーマッ プ (41) と (b) 溶媒和 PMF マップを比較する (42)。図 3 (a) の工 ネルギーマップにおいて最安定極小点に相当する“a”極小 点が図 3 (b) のPMF マップ上では最もエネルギーの高い極小 点へ、逆に最もエネルギーの高い図 3 (a)の の “e 極小点が図 3 (b) の最安定極小点 “w”へと変化した。このようなポテン シャル曲面の変化は主に溶媒和による効果と考えられ、実際、 キシロビオースの例と同様に水分子が介在する残基間水素結 合が極小点配座に打いて確認された。また、カラギーナン分 子鎖の結晶構造 (図 3 (a)の の”) が PMFマップ曲面の最安 定極小点の近傍に相当することも興味深い結果である。なお、 カラギーナンの別の繰り返し単位であるカラビオースについ ては、以上のような明確な溶媒和効果が確認されなかった(43)。

( 注 1) 立体配座解析とは目的分子の立体配座空間を評価し 具体化するため、重要な構造パラメーターに対する極小点の 位置とエネルギー值で構成されるトポロジー (ポテンシャルエ ネルギー曲面)を作成する手段である。

( 注 2) 緩和残基によるエネルギーマップ計算では、 $\Phi-\Psi$ 值を固定したまま残りの立体構造を最適化させ、得られた立

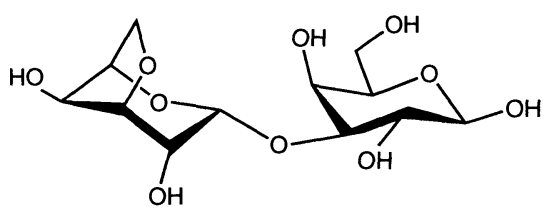

Scheme 1 Structure of neocarrabiose. 

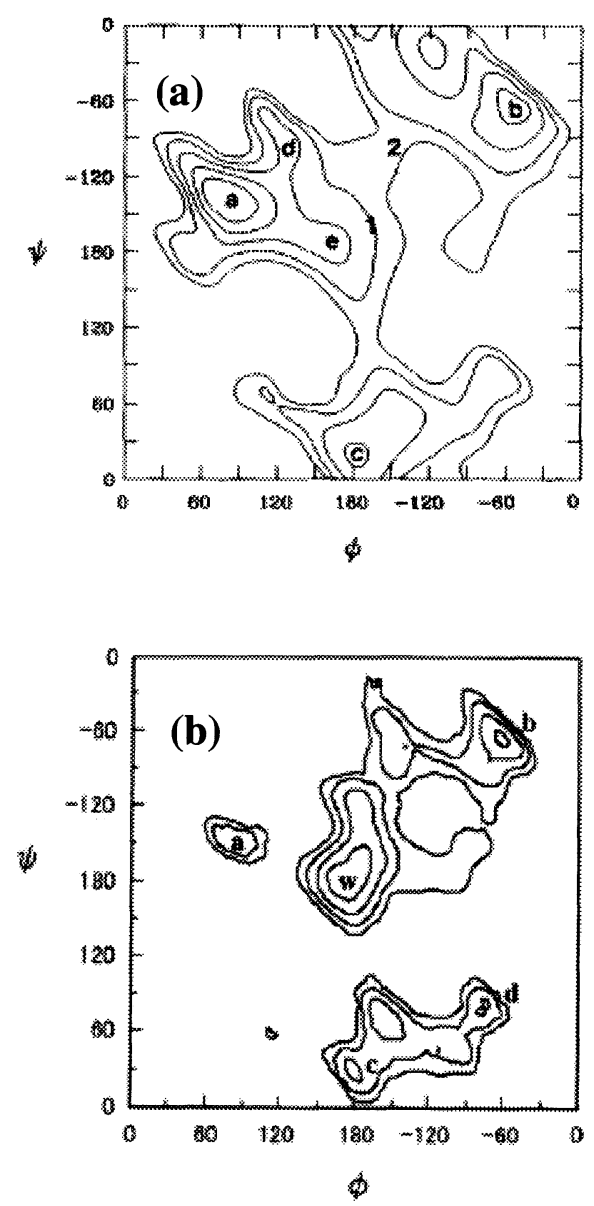

Fig. 3. (a) "Relaxed residue" energy and (b) potential mean force maps for neocarrabiose. Counter lines are drawn in $1 \mathrm{kcal} / \mathrm{mol}$ increments above the global minimum. Positions of local minima are indicated by letters from "a" to "e", and "w". [Reprinted with permission from Ref. 41 (p.463) Copyright 1996 John Wiley \& Sons, Inc. and from Ref. 42 (p.1958) Copyright 2004 Elsevier Ltd.]

residue geometry is optimized except the $\Phi-\Psi$ rotations. Its surface is constructed by the steric energy at each $\Phi-\Psi$ grid point. In other words, the energy surface corresponds to the projection of the lowest steric energy onto each $\Phi-\Psi$ grid point, which, therefore, is termed "adiabatic" energy map.

\section{Oligo- and Polysaccharide Modeling}

Oligo- and polysaccharide modeling are primary based on the relaxed-residue $\Phi-\Psi$ energy map of a component disaccharide unit. The three-dimensional structures of the molecules are generated by at first combining the $\Phi-\Psi$ minimum conformations on energy maps and then linking the residues with these conformations. Stable helix conformations of simple homopolysaccharides can readily be predicted based on the rigid-residue energy map, which actually were used as the initial models in their crystal structure modeling (2, 3). Brant et al. attempted to model the solution structures of polysaccharides using a combination of the $\Phi-\Psi$ energy map calculations and the Monte Carlo (MC) method. Unexpectedly,
体エネルギー值をもとにポテンシャルエネルギー曲面を構築 する。言い換えれば、このエネルギー曲面は二糖分子がとり うる最も安定な立体エネルギー量を $\Phi$ - $\Psi$ グリッド点に投影し たもので、それゆえ“断熱”エネルギーマップとも呼ばれる。

\section{D. オリゴ糖鎖および多糖類分子鎖の分子モデリング}

オリゴ糖および多糖類分子の分子モデリング手段は構成 二糖分子の緩和残基 $\Phi-\Psi$ ポテンシャルエネルギーマップの 作成を基本とし、まずエネルギーマップ上の安定配座の組み 合わせにより糖残基を連結してゆき、オリゴ糖、多糖類分子 鎖の立体構造へと拡張する。単純なホモ多糖分子鎖に関する 限り固定残基マップからでも安定らせん配座が容易に予測さ れ、これらは各種の多糖類結晶構造解析の初期モデルとして 利用された $(2 、 3)$ 。 Brant らは $\Phi$ - $\Psi$ エネルギーマップとモンテ カルロ法 $(\mathrm{MC})$ の組み合わせにより多糖分子の溶液構造モデリ 
the MC simulations based on the less precise, rigid-residue maps resulted in better prediction of the observed physical properties of a solution than those based on the relaxedresidue maps (44). Kitamura et al. applied the MC calculations to sample solution structure models for the small angle $\mathrm{X}$-ray scattering studies of maltose oligomer (45), cyclicamylose (46), and ( $1 \rightarrow 3)$ - $\beta$-D-glucan (47).

In the case of modeling of heteropolysaccharides which consist of more than a single type of linkage structure or residue, one must examine all possible combinations of the glycosidic conformations present in the repeating unit, which causes an abrupt increase in the number of helical conformation patterns. The "grid search" method explores exhaustively all possible conformational states. In order to study the helical conformation behavior of heteropolysaccharides, the authors proposed the helix parameters, $n-h(*)$, mapping method (48), in which the helix models generated by the $\Phi-\Psi$ grid search were projected to each $n$ - $h$ grid point. The method was applied to Beijeran, acidic heteropolysaccharide, (Scheme 2) (49), two types of heteroglucans, Elsinan, poly [(1 $\rightarrow 3)$ - $\alpha$-D-maltotriose], and Lichenan, poly [( $\rightarrow 3)-\beta$-D-cellotriose] (50), and branched $(1 \rightarrow 3)$ - $\alpha$-D-glucan (Scheme 3) (51), whose helical properties were described by the respective maps. In these mapping studies, all of the $\Phi-\Psi$ grid points of the low energies with a $10^{\circ}$ interval on each map were combined to generate helical models. In addition, the modeling studies of the three heteroglucans, except for Beijeran, calculated the steric energy of each helix model using the PFOS force field, which provided the $n-h$ density maps of the helix model population with energy weighting. It was observed that the $n-h$ positions corresponding to the helix density peak were in
ングを試みたところ、緩和残基マップより精度の低い固定残 基マップの方が溶液物性の実験值を再現するという予期しな い結果を得た (44)。Kitamura らは小角 X 線散乱データ (SAXS) 解析に用いる立体構造モデルのサンプリングを目的として、 マルトオリゴ糖 (45)、大環状アミロース (46) および (1 $\rightarrow 3)-\beta-1$ グルカン (47)の MC 計算を報告した。

二種類以上のグリコシド結合または残基で構成されるへ テロ多糖類分子鎖の場合、構造単位に含まれるグリコシド結 合のすべてに対応するエネルギーマップを組み合わせるた め、発生する配座パターン数は一気に増大する。この際、す べての配座を網羅的に検討してゆくアプローチを“グリッド 探索”と呼ぶ。筆者はへテロ多糖類分子鎖のらせん形成挙 動の解析を目的として、 $\Phi-\Psi$ 点のグリッド探索法から生成 したらせんモデルをらせんパラメーター $n$-hマップ(48)( 注 1) に投影する方法を提案した。この方法を酸性へテロ多糖であ る Beijeran（スキーム 2)(49)、2 種のヘテログルカン、Elsinan、 poly[ $(1 \rightarrow 3)-\alpha$-D-maltotriose $] 、 と$ Lichenan、poly[ $(1 \rightarrow 3)-\beta$-Dcellotriose]、(50)、および分岐状 (1 $\rightarrow 3$ )- $\alpha$-D- グルカン ( スキー ム 3)(51) に適用し、それぞれの分子鎖が示すらせん特性を $\mathrm{n}-\mathrm{h}$ マップで表現した。らせんモデルは構成二糖の M M 3 緩和残基 エネルギーマップを計算し、マップ上の安定配座 $\Phi-\Psi$ 点をグ リッド幅 $10^{\circ}$ 間隔ごとに組み合わせるプロセスにより生成し た。さらにBeijeran を除く三種のへテロ多糖類計算において は生成したらせんモデルの立体エネルギーをPFOS力場によ り評価し、エネルギー評価を含めた $n$ - $h$ らせん密度分布マップ

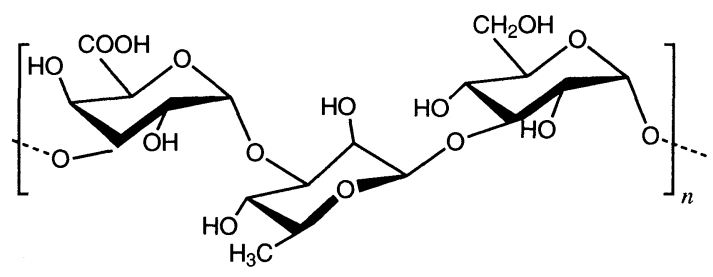

Scheme 2. Chemical repeating unit of Beijeran.

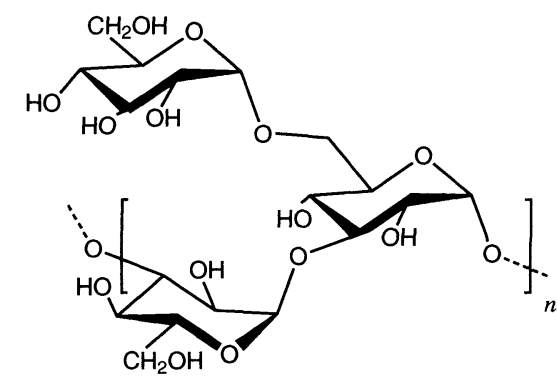

Scheme 3. Chemical repeating unit of branched $\alpha$-glucan. 
good agreement with those derived from the X-ray diffraction data $(49,50)$. Branched $(1 \rightarrow 3)$ - $\alpha$-D-glucan was modeled by combining the backbone $\alpha-1 \rightarrow 3 \Phi-\Psi$ and branching $\alpha-1 \rightarrow 6 \Phi-\Psi$ conformations (51). Figure 4 compares the $n-h$ density maps of the branched glucan (a) and the linear (1 $\rightarrow 3$ )- $\alpha$-D-glucan (poly[ $(1 \rightarrow 3)$ - $\alpha$-D-nigerose $]$ ) as a control polysaccharide. Both maps exhibit similar distribution ranges with respect to the $n-h$ dimensions, indicating that the branched residue does not significantly restrict the backbone conformation. The branched residue rather plays a role in stabilizing the helical structures with certain $n$ - $h$ values. Figure 5 depicts the three most stable helical conformations proposed for $\alpha$-glucan. The most stable model (a) exhibits a loosely wound structure defined by the helix parameters of $n=9.6$ and $h=5.91 \AA$. As shown in the figure, the branching residues are exclusively placed at one side of the helical chain, resulting in the residues spatially adjoining to each other. As a result, the inter-residue hydrogen bonds are formed between the branching residues, in addition to the ordinary bonds within the backbone residues. The second (b) and third (c) lowest helix models conformed with the helix parameters of $n=7.1$, $h=8.4 \AA$ and $n=4.4, h=6.8 \AA$, respectively, both having the branching residues spatially distributed. Inter-residue
を作成した。これらの $n$ - $h$ マップのらせん分布密度ピークに 相当する $n-h$ 值は X 線回折データとほほ一致した $(49.50)$ 。分 岐状 $(1 \rightarrow 3)-\alpha$-D- グルカンのらせんモデル生成においては $\alpha-1$ $\rightarrow 3$ 結合主鎖の $\Phi-\Psi$ 配座に $\alpha-1 \rightarrow 6$ 結合側鎖の $\Phi-\Psi$ 配座を 組み合わせた (51)。図 4 (a) に分岐状 $\alpha$-グルカン、(b)にコン トロールとして計算した直鎖状 $\alpha$-グルカン $(\operatorname{poly}[(1 \rightarrow 3)-\alpha-1)-$ nigerose])の 2 種の $n-h$ らせん密度分布マップを比較する。こ れより、許容らせん分布の範囲は両方のマップでほほ等しい ことから主鎖配座は分岐残基による制限を受けないことが分 かった。一方、分岐残基の存在により分岐状 $\alpha$ グルカンにお いて特定の $n-h$ 領域のらせん構造が安定化される傾向が確認さ れた。図 5 に分岐状 $\alpha$-グルカンが示す 3 種の安定配座モデル を示す。最安定モデル (a) は、らせんパラメーター、 $n=9.6 、$ $h=5.91 \AA$ で定義されるゆるく巻いたらせん構造である。図 4 で示されるように、側鎖残基がらせん軸の一方に集中するた めそれらの空間配置が近接し、その結果、主鎖残基間に加え 側鎖残基間で水素結合を形成している。第二安定 (b) および第 三安定モデル (c) のらせんパラメーターは、それぞれ、 $n=7.1$ 、 $h=8.4 \AA$ および $n=4.4 、 h=6.8 \AA$ となり、いずれのらせんモ
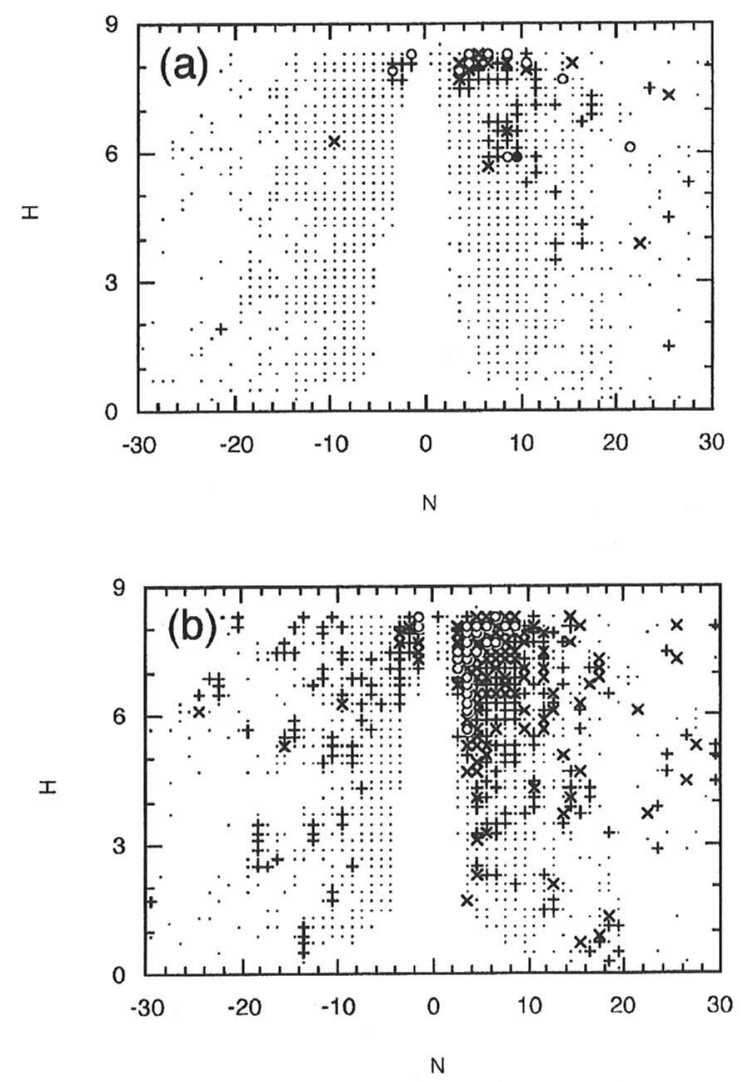

Fig. 4. Energy and population weighted $\boldsymbol{n}$ - $\boldsymbol{h}$ density maps for (a) branched $\alpha$-glucan and (b) poly[(1 $\rightarrow 3)-\alpha-D-n i g e r o s e]$. Density values at each $n-h$ grid point are indicated by the notations of either; ( ) $10-100 \%,(O) 1-10 \%,(\times) 0.1-1 \%$, (+) $0.01-0.1 \%$, or (_) less than $0.01 \%$. [Reprinted with permission from Ref. 51 (p.57). Copyright 2000 Japan Society for Bioscience, Biotechnology, and Agrochemistry.] 

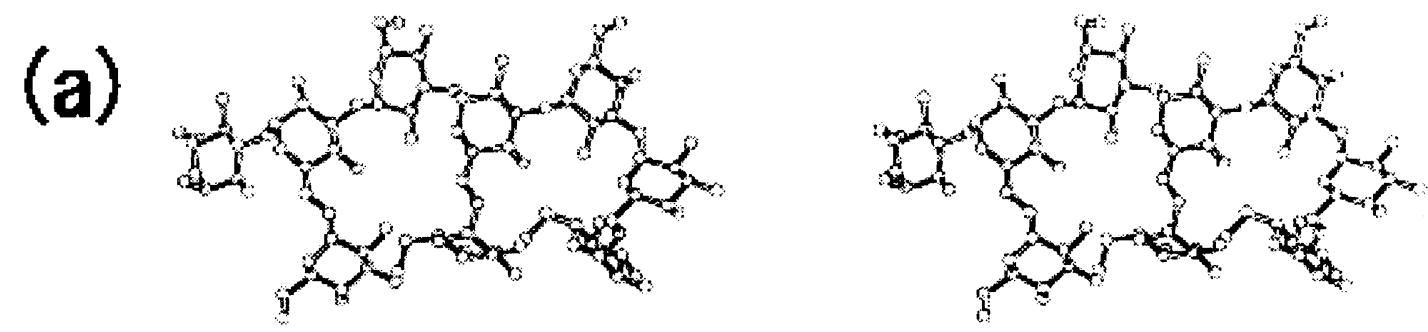

(b)
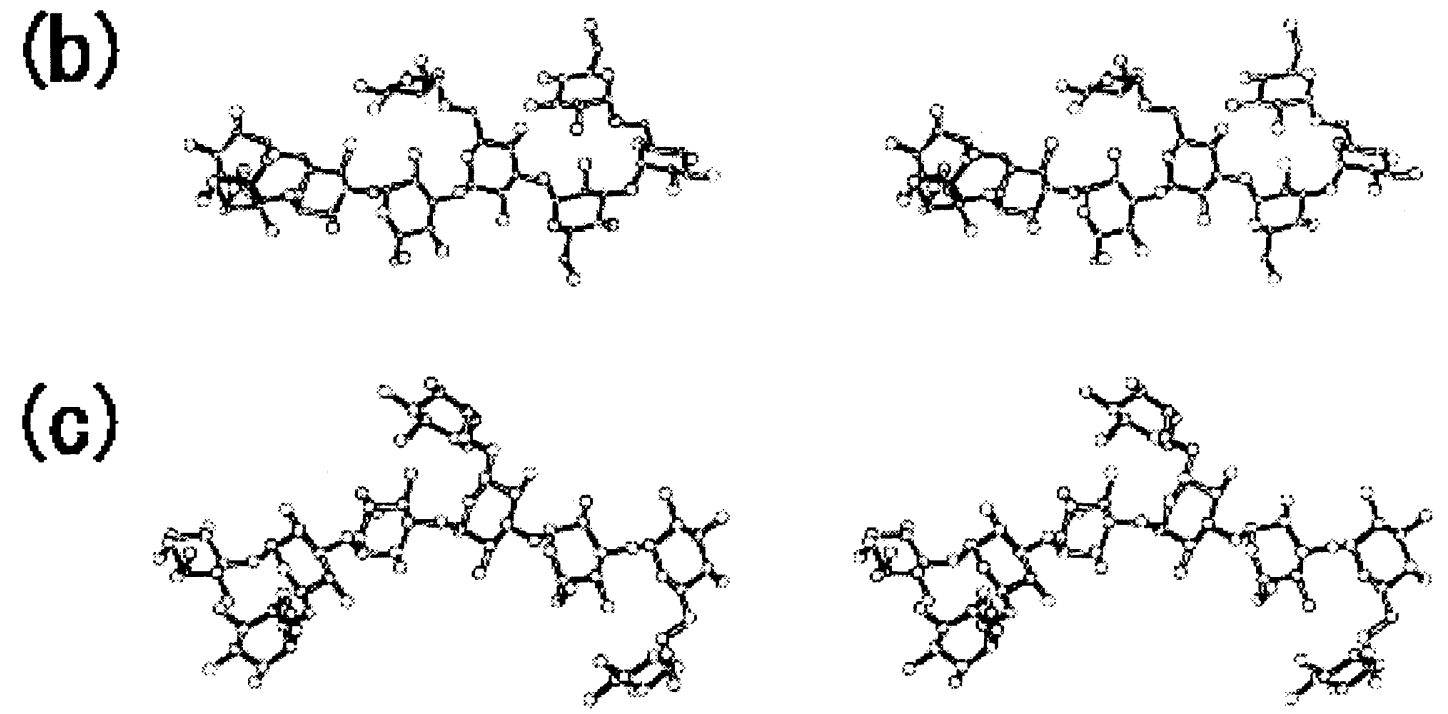

Fig. 5. Stereoscopic views of the three lowest conformations proposed for $\alpha$-glucan. The fragment of three chemical repeating units is depicted with its helix axis lying horizontally. [Reprinted with permission from Ref. 51 (p.59). Copyright 2000 Japan Society for Bioscience, Biotechnology, and Agrochemistry.]

hydrogen bonds were formed within the backbone residues and between the backbone and branching residues for the (b) model, and within the backbone residues for the (c) model. Since such a variation in an inter-residue hydrogen bond scheme may affect the stiffness of a whole chain, it is expected that the diversities may arise in the physical properties of the solutions and materials of $\alpha$-glucan depending on a branching conformation.

The rigid-residue modeling discussed above was likely to overestimate the interactions arising between the branched and backbone residues. In order to perform a more quantitative analysis, the conformation search accompanying a complete optimization should be examined, as was the case with the disaccharide map calculations. The combined procedure of the grid search followed by the complete structure optimizations was adopted for the modeling study of the O-specific polysaccharide which was the cell wall component lipopolysaccharides of virulent Shigella dysenteriae (Scheme 4) (52-54). The allowed $\Phi-\Psi$ conformations extracted form the MM3 relaxed-residue energy maps of the component disaccharides which were combined to generate about 24,000-310,000 helix models, and were successively
デルにおいて側鎖残基は互いに離れた配置をとっている。こ れらのらせんモデルの残基間水素結合は、らせんモデル (b)で は主鎖残基間と側鎖残基 - 主鎖残基間に、らせんモデル (c) で は主鎖残基間において形成された。このような残基間水素結 合様式の違いから、モデル間で分子鎖全体の剛直性が異なり、 それゆえ側鎖残基の配座に依存して $\alpha$-グルカンの溶液や材料 物性に多様性が生じることが予想される。

上で紹介した固定残基による分岐状多糖類分子鎖のモデ リング計算は分岐部残基と主鎖残基の相互作用を過大に評価 する可能性があり、より定量的な配座解析を行うためには二 糖分子のエネルギーマップと同様に糖鎖全体の構造最適化を 伴った探索法により安定配座を検討すべきである。グリッド 探索とそれに続く構造最適化計算の併用による探索プロセス が合成糖鎖抗体の分子設計を目的として実施された病原性 Shigella dysenteriae 細胞壁りポ多糖の構成 O- 抗原性多糖( スキー ム 4) の立体配座解析に適用された (52-54)。構成二糖の MM3 緩和残基エネルギーマップ上の許容領域内に含まれる $\Phi-\Psi$ 配 座点を組み合わせて生成した約 24,000〜310,000 のらせんモ デルに対して、パラメーターを改良したHSEA 力場 (55) また 


\section{Type 1}

$$
[\rightarrow 3]-\alpha-L-R h a p-(1 \rightarrow 3)-\alpha-L-R h a p-(1 \rightarrow 2)-\alpha-D-G a l p-(1 \rightarrow 3)-\alpha-D-G l c N A c p-(1 \rightarrow]_{n}
$$

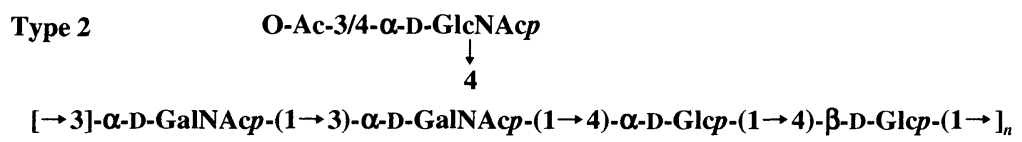

Scheme 4 Chemical repeating units of $\mathrm{O}$-specific polysaccharides of $S$. dysenteriae.

optimized using either the HSEA force field with the modified parameters (55) or the MM3 force field. In the type 1 polysaccharide having the linear tetrasaccharide repeating unit, the most stable helix model involved the second lowest $\Phi-\Psi$ conformations in the MM3 maps (52). On the other hand, the type 2 polysaccharide consisting of the branched pentasaccharides adopted the lowest $\Phi-\Psi$ conformations in the backbone conformation (53). It was indicated in the type 4 polysaccharide, another branched pentasaccharide sequence, modeling that the branch $\alpha$-L-fucose residue did not appreciably affect the backbone conformation (54).

In the grid search, the conformational space to be explored exponentially increases as the internal flexibility increases in larger molecules. Therefore, it is virtually unrealistic for the method to be applied to the oligosaccharides of larger than ten sugar units that are generally found in most glycoconjugate molecules. So far, various search algorithms to extract effectively stable conformations have been proposed. Among the algorithms, the CICADA (Channels in Conformational Space Analyzed by Driver Approach) method $(56,57)$ will be described in the present section. The method allows one of the important torsion angles, giving a significant effect on a molecular shape, to step with an interval of a few to ten several degrees, and the whole structure was optimized except the torsion angle at each step. In the course of the stepping, the three-dimensional structure of the molecule may move along the low energy valley in its conformational space so that one can "expect" that most of the conformational minima and transition states are explored by rotating all the important torsion angles in both clockwise and anticlockwise directions. The CICADA method was applied to the MM3 molecular modeling of the 14 kinds of the $\mathrm{ABH}$ and Lewis specific oligosaccharides, and the stable conformations for each oligosaccharide were proposed (58). When comparing
は MM3 力場計算による最適化構造を求めた。直鎖状四糖の繰 り返し単位を持つ type1 多糖では構成二糖分子エネルギーマッ プの第二安定配座点が多糖分子鎖の最安定らせんモデルに相 当した (52)。一方、分岐状五糖ユニットで構成される type2 多 糖においては二糖の最安定配座が最安定らせんモデルにおい ても保持された (53)。別の分岐状五糖ユニットを持つ type4 多 糖では側鎖残基 $\alpha$-L-フコースが主鎖配座にさほど影響しない ことが示された (54)。

すべての配座空間を探索するグリッド探索法では分子が 大きくなり内部自由度が増加するに伴って指数関数的に探索 すべき配座空間が増大する。従って、多くの複合糖質を構成 する 10 残基を超えるような糖鎖分子に対してグリッド探索法 を適用することは事実上不可能となる。これまで効率的に安 定配座を抽出する様々な方法が提案されてきたが、ここでは Koča によって提案された CICADA (Channels in Conformational Space Analyzed by Driver Approach) 法について紹介する (56、57)。 この方法では分子立体構造に大きく影響する重要な結合回転 角を数度〜十数度のステップ幅で変化させ、それぞれのステッ プでその結合回転角を固定した状態で全体構造を最適化させ る。このステップ変化の過程で立体構造は配座空間上の安定 エネルギーの谷間を移動するため、選ばれた結合回転角のす べてについてそれぞれ時計回りと反時計回りの両方向に同様 な探索を行うことにより、立体配座空間を構成するほぼす心゙ ての極小点と遷移状態が網羅されると“期待する”。この CICADA 法は 14 種類の ABH 型㧍よびルイス型糖鎖を対象と した分子モデリング計算に適用され、それぞれの糖鎖分子に ついて安定配座モデルが提案された (58)。すべての糖鎖の極 
all the minimum conformations thus obtained, the minimized structures of the oligosaccharides specific to the same blood type but differing in the chemical structures displayed similar structures to each other. Such structural similarity had been already observed in the rigid-residue modeling studies on the $\mathrm{H}$ type oligosaccharides, and $\mathrm{Le}^{\mathrm{a}}$ and $\mathrm{Le}^{\mathrm{b}}$ specific ones (59, $60)$.

The CICADA method was also adopted for larger molecular systems, an uromojulin O-linked oligosaccharide which consists of 14 residues (14 glycosidc linkages)-three sialyl Lewis branchs and a disaccharide core (Scheme 5) (61). All the $\Phi-\Psi$ torsion angles of 28 linkages were driven by $15^{\circ}$ step and the resulting $11,471 \Phi-\Psi$ conformations were optimized with respect to the MM3 force field. The 2,637 models found in the conformational space within $4 \mathrm{kcal} \mathrm{mol}^{-1}$ above the lowest conformation were selected as acceptable ones. The result indicated that the CICADA search considerably suppressed the number of conformations to be explored and extracted stable conformations with much higher efficiency of $23 \%$, compared with the grid search. When classifying all the stable conformations, it was found that $95 \%$ populations of them comprised the four classes and that the C-branch exhibited most conformational flexibility among the three Lewis branches.

In principle, although prolonged MD calculations could allow any molecule to trace all possible conformations, it is not readily observed even in disaccharides that the structural change as much as a $\Phi-\Psi$ conformational transition occurs during a realistic computational time. The MD calculation has been rather used to study dynamic behavior in a local structure. MD studies of glycoprotein oligosaccharides have been frequently reported because they were regarded as a model compound for branched oligosaccharide modeling as well as their physiological significances (62). Among the
小点構造を比較したところ、化学構造が異なるが同じ血液型 特異性を示す糖鎖分子は互いによく似た最適化構造を示した。 この報告より以前に $\mathrm{H}$ 型糖鎖および $\mathrm{Le}^{\mathrm{a}}$ と $\mathrm{Le}^{\mathrm{h}}$ 型糖鎖について 行われた固定残基によるモデリング研究においても同様な類 似性が確認された (59、60)。

CICADA 法はさらに大きな糖鎖分子である三つのシアリ ル $\mathrm{Le}^{\mathrm{x}}$ 分岐と二糖コア部分の 14 残基 (14 グリコシド結合) か ら構成された uromojulin-O 結合型糖鎖 (スキーム 5)の安定配 座探索に対しても適用された (61)。28 ケ所のすべてのグリコ シド結合回転角 $\Phi-\Psi$ を $15^{\circ}$ ステップで変化させ、これより 生成した 11,471 個の $\Phi-\Psi$ 配座モデルに対して MM3 構造最適 化を適用し、最安定構造から $4 \mathrm{kcal} \mathrm{mol}^{-1}$ 以内に検出された2,637 個を安定配座モデルとした。この結果は、グリッド探索を適 用した場合と比べてはるかに探索配座点数が抑えられ、さら に $23 \%$ と極めて効率よく安定配座が抽出されたことを示して いる。これらの安定配座を分類したところ、比較的大きな糖 鎖分子であるのにも関わらず 4 種類の配座タイプが全体の 95 \%の分布量を占めた。また、三つのシアリル $\mathrm{Le}^{\mathrm{x}}$ 分岐糖鎖の うち C 位置の糖鎖の立体配座が最も大きな柔軟性を示した。

原理上、長時間の MD 計算を実施すれば目的分子がとり うるすべての立体配座を探索することは可能であるが、現実 的な計算時間内で $\Phi-\Psi$ 配座変換にまで及ぶ立体配座変化を 発生させることは二糖分子でさえも容易でない。むしろ MD 計算法は局所的な構造の動的挙動を検討するために利用され た。生理学的に重要な血液型特異性糖鎖や糖タンパク質糖鎖 は、分岐糖鎖モデリング研究のテスト化合物としても位置づ けられ、多くの MD 研究例が報告されている (62)。それらの 計算結果より血液型特異性糖鎖は比較的、固定された立体構
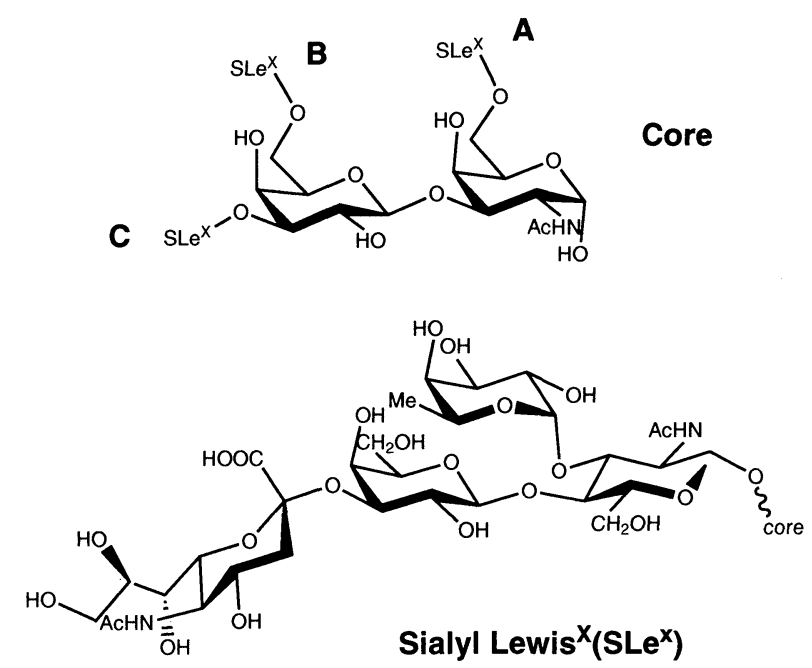

Scheme 5 Representations of core disaccharide and S-Le ${ }^{\mathrm{x}}$ structure of uromodulin O-glycan. 


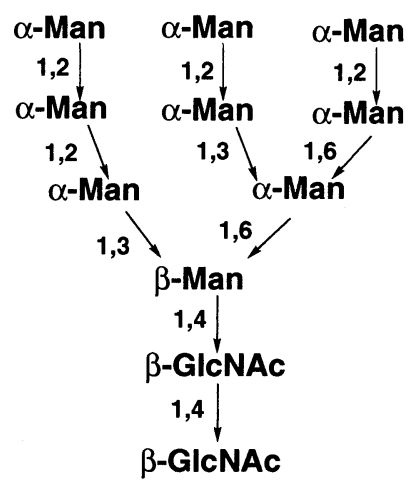

\section{Scheme 6. Schematic representation of high mannose type N-linked oligosaccharide G2M9.}

results, while the blood type specific oligosacchrides was shown to conform with relatively rigid three-dimensional structures $(63,64)$, the oligosaccharide units in the $\mathrm{N}$-linked glycoproteins adopted flexible structures, where conformational transitions were observed at not only the terminal residues but also the branching units (65-68). Balaji et al. proposed the concept of "conformational driven" pathways to describe the processing sequence of $\mathrm{N}$-linked oligosaccharides $(66,67)$. In the studies, the MD calculations using the CVFF force field suggested three representative stable conformations for the oligomannnose, G2M9, (Scheme 6 ), each of which was characterized by a structure where one of three terminal mannoses was exposed to solvent. This suggested that, on the processing at endoplasm, the three kinds of $\alpha-1 \rightarrow 2$ specific mannosidase recognized one of three terminal mannoses of G2M9, resulting in the three different G2M8 oligosaccharides. The processing pathway model based on the stable conformations was further applied to discuss the following processing sequence up to G2M5, and the pathways of the hybrid and complex type oligosaccharides (69). The calculations may have been unreliable because no solvent system was introduced, due to the limitations of hardware power, and the usage of the CVFF force field that had then no refined parameter sets for carbohydrates. The concept of a conformational driven pathway, however, still seems to be interesting and recalculation with more precise conditions is worth being attempted. As regards the MD study on G2M9, the solvated calculations with explicit water molecules were carried out adopting the AMBER-GLYCAM parameters (70). During 1ns simulation, while local flexibility took place due to the $\Phi-\Psi$ conformational transitions, these transitions correlated with each other so as to cause no significant effect on variations of the overall structure. In addition to ordinary interresidue hydrogen bonds, the water-mediated hydrogen bonds between the $\alpha-1 \rightarrow 2$ linked residues and between the terminal residues on the branches were detected. It was also indicated that some of the hydroxyl groups on the branching unit residues established stable interactions with
造をとることが示されたが $(63 、 64) 、 \mathrm{~N}$ 結合型糖タンパク質糖 鎖の立体構造は柔軟であり、糖鎖末端部分の残基だけでなく 分岐部分においても配座変換が確認された(65-68)。Balajiらは、 $\mathrm{N}$ 結合型高マンノース型糖鎖のプロセッシング過程のモデル として” conformational driven”代謝経路を提案した $(66,67)$ 。 CVFF力場を用いた MD 計算の結果、オリゴマンノース糖鎖 G2M9 (スキーム 6) が示す 3 種の代表的な安定配座は三力所の 非還元末端側マンノース残基のいずれかが溶媒中に露出する 分子形態に相当した。このことより細胞内の糖鎖プロセッシ ング過程において 3 種の異なる $\alpha 1 \rightarrow 2$ 特異的マンノシダーゼ が G2M9 の末端マンノース残基のいずれかを認識し、その結 果 3 種の G2M8 糖鎖を与える経路が提案された。この様な安 定立体配座を根拠とするプロセッシング経路のモデルはその 後の G2M5 に至るまでの過程や、さらに混成型や複合型糖鎖 の場合 (69)についても検討された。これら計算は当時のハー ドウェア能力の制限から溶媒分子を考慮しておらず、また精 密な糖鎖パラメーターを持たないCVFF力場による計算であっ た等、いくつかの理由から計算結果の信頼性に問題があるが、 彼らの “conformational driven” 代謝経路に関するアイデアは 興味深く、さらに精度の高い方法による再計算を試みる価值 はある。G2M9 糖鎖に関して、さらに、AMBER-GLYCAM パ ラメーターを用いて水分子を明示的に設定した溶媒和 MD 計

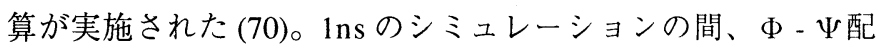
座変位により局所的な柔軟性が生じる一方で、それらが互い に相関するため糖鎖全体の基本構造は大きく変化しなかった。 また、通常の残基間水素結合に加えて $\alpha 1 \rightarrow 2$ 結合残基間や分 岐末端残基間で水分子が介在する水素結合が確認され、さら に分岐部残基の一部の水酸基において水分子との安定した相 互作用が示された。図 6 に、同様なAMBER-GLYCAM パラメー 

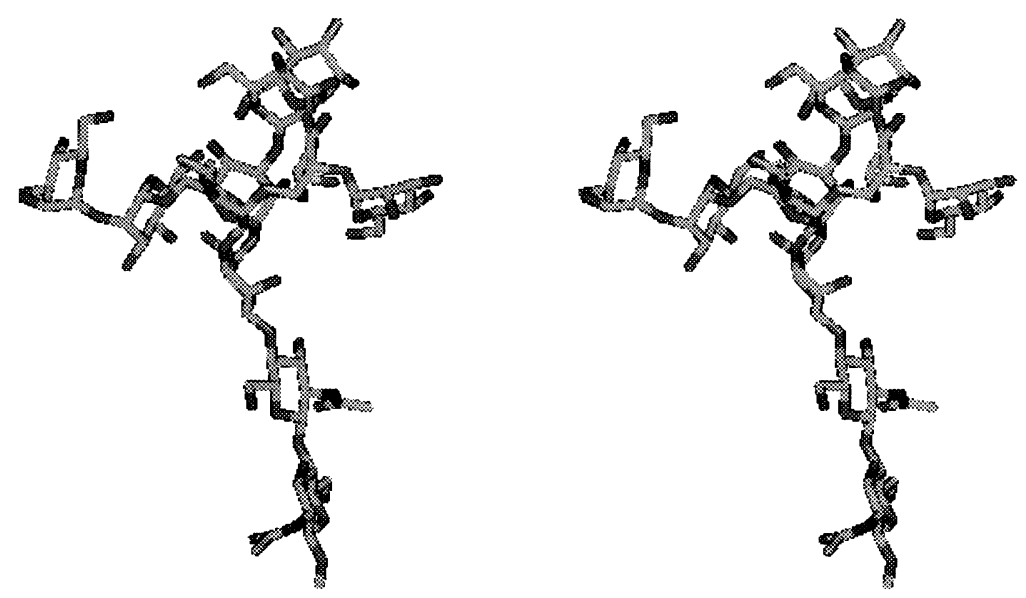

Fig. 6. Stereoscopic view of a representative conformation of G2M9 N-linked oligomannose.

water molecules. Similar MD simulation of G2M9 using AMBER-GLYCAM parameters and explicit water molecules for salvation was carried out by the authors (71). Figure 6 shows a representative conformation of the oligomannose, which exhibits the three branching, nonreducing terminals expanding into different direcctions to establish the maximum interactions with surrounding water molecules. For another $\mathrm{N}$-linked oligosaccharide consisting of eight residues, the CHARM-HGFB MD calculations were reported in order to compare between the dynamic behaviors of the oligosaccahrides in the two different solvated environment i.e. the isolated and lectin binding states $(72,73)$. It was suggested in the simulation study that the conformation of the lectin binding oligosaccharide was subject to virtually no restriction from the surroundings, exhibiting a similar behavior to that of the isolated oligosaccharide.

$\left.{ }^{*}\right)$ The helix parameters are: $n$, the number of chemical repeating unit per helical turn; $h$, the projection length of the repeating unit on the helix axis in $\AA$.

\section{E. Conclusion}

The solution studies of the carbohydrate molecules discussed in the present review reported a fairly good agreement between the ensemble averaged structure derived from the stable conformations and the experimental data in solution obtained by, for example, NMR measurement. As for polysaccharides, their modeling calculations predicted reasonably well the helical structures observed in the X-ray fiber diffraction data. These results obviously suggested that, on the contrary to the polypeptide modeling where its secondary structure and folding pattern could be proposed by the knowledge based predictions, the three-dimensional structures of oligosaccharides and polysaccharides would be predictable with practical precision by theoretical calculations on the computational chemistry basis. It is not straightforward by any means to predict how much and what variations of
ター+ 溶媒和 MD 計算により著者らが求めた G2M9の代表的 な安定配座を示す $(71)$ 。これより、三つの非還元側分岐糖鎖 が異なる方向に張り出し、周囲の溶媒と最大に接触している 分子形態が確認される。8 残基で構成された別の $\mathrm{N}$ 型結合型 糖鎖を対象として、孤立状態掞よびレクチン結合状態の 2 種 の溶媒和環境における糖鎖が示す動的挙動の比較を目的とし たCHARM-HGFB MD計算も報告された。このシミュレーショ ン研究からレクチン上であっても糖鎖構造は周囲の環境から ほとんど制限を受けず孤立状態の溶液構造とよく似た挙動が 示された (72、73)。

(注 1) らせんパラメーター：n、らせん一巻を構成する繰 り返し単位の数 $; h$ 、繰り返し単位がらせん軸に投影する長さ ( $\AA$ )。

\section{E. 結 論}

本レビューで紹介された糖質分子の溶液構造に関する研 究成果は、安定配座から得られたアンサンブル平均構造と NMR 測定等による溶液構造データが良く一致すると報告し ている。また、多糖類分子鎖に関しても分子モデリング計算 は X 線紼維図形データが示すらせん構造をほぼ予測した。以 上の成果から、ポリペプチド鎖の二次構造やフォールディン グは知識ベースに基づいて予測されるのに対して、糖質分子 の立体構造は計算化学を背景とした理論計算により実用的な 精度で予測可能であることが示唆された。化学構造上の変化 が立体構造に与える影響は、決して単純でない。例えば、多 糖類分子鎖の主鎖残基にアセチル基のような置換基を導入し ても主鎖の立体化学に根本的な变化は生じないが、分岐状多 糖類分子であるザンタンガムでは分岐部糖残基のア七チル化 
chemical structure affect the three-dimensional structure. For example, no fundamental change in the backbone structure often occurs in most polysaccharide chains as a result of introducing substituents, such as acetyl groups, into the backbone residue. In xanthane gum chain, actetylation of the branch residue considerably restricted the backbone flexibility $(74,75)$. Therefore, even for the modeling study of oligosaccharide composed of a few residues, it is always required not only to select a set of reliable parameters and force field but also to perform conformational analysis in order to inspect all possible conformations including substituent orientations. As was discussed above, knowledge of the global minimum structure may not always be enough to interpret the solution structure data. In addition, the authors also wish to point out from this respect that certain oligosaccharides bound to the receptor proteins or to the enzymes do not always adopt the most stable structure. Protein recognition of oligosaccharides is still a challenging target for the carbohydrate modeling study. With advances in protein modeling based on genetic information, further development of the carbohydrate-protein complex modeling is also expected, which has not been discussed in the present review.
よって主鎖立体配座の柔軟性が大きく制限された $(74 、 75)$ 。し たがって、3-4 残基程度の糖鎖のモデリング計算においても、 信頼性の高い力場やパラメーターを選択するだけでなく、立 体配座解析により置換基の配向を含めたあらゆる立体配座の 可能性について検討すべきである。上で述べたように、たと え最安定配座モデルが得られたとしても溶液構造のデー夕解 析に十分ではない可能性が高く、このことと関連して受容体 タンパク質や糖質関連酵素と結合した糖質分子が必ずしも最 安定配座をとらないことも指摘しておきたい。一方、タンパ ク質による糖鎖認識は分子モデリング研究の対象として興味 深いテーマである。今回のレビューでは紹介しなかったが、 遺伝子情報に基づいたタンパク質モデリング研究の発展に 伴って糖鎖 - タンパク質複合体のモデリング研究の今後の展開 が期待される。

\section{References}

1. Woods, R.J. (1995) Curr. Opin. Struct. Biol. 5, 591-598

2. Chandrasekaran, R. (1997) in "Advances in Carbohydrate Chemistry and Biochemistry" (Horton, D. ed.), Academic Press, Vol. 52 , pp. 311 $-438$

3. Yui, T., and Ogawa, K. (2005) in "Polysaccharides, Structural Diversity and Functional Versatility" (Dumitriu, S., ed.), Second Edition, Marcel Dekker, New York, pp. 99-122

4. Jeffrey, G.A., and Saenger, W. (1991) "Hydrogen Bonding in Biological Structures", Springer-Verlag

5. Schmidt, K. Tsaki, and Brady, J.W. (1994) J. Food Eng. 22, 43-57

6. Woods, R.J., Fraser-Reid, B., Dwek, R.A., and Edge, C.J. (1993) in “Modeling the Hydrogen Bond” (Smith, D., ed.), ACS Symposium Series 569. American Chemical Society, Washington, DC, pp. 252-268

7. Kirschner, K.N., and Woods, R.J. (2001) Proc. Natl. Acad. Sci. USA 98, 10541-10545

8. Woods, R.J. (1989) Glycoconjugate J. 15, 209-216

9. 例えば:大澤映二編、計算化学入門」1994年、講談社サイエンティフィク;U. Bruckert、N.L. Allinger著、大澤映二、竹内敬人訳、「分 子力学」1986 年、啓学出版 (分子力学法); 岡崎進著、「コンピュータシミュレーションの基礎」2000 年、化学同人(分子動 力学法) ; 岡崎進、岡本祐幸編、「生体系のコンピュータシミュレーション」(タンパク質の分子モデリング法)。

10. Tvaroska, I., and Bleha, T. (1989) in “Advances in Carbohydrate Chemistry and Biochemistry” (Hroton, D., ed.), Academic Press, Vol. 47. pp. $45-123$

11. Tvarosak, I., and Carver, J.P. (1994) J. Phys. Chem. 98, 6452-6458

12. Tvarosak, I., and Carver, J.P. (1994) J. Phys. Chem. 98,9477-9485

13. Lemieux, R.U., and Koto, S. (1974) Tetrahedron 30, 1933-1944

14. Bock, K. (1983) Pure Appl. Chem. 55, 605-622

15. Tvaroska, I., and Pérez, S. (1986) Carbohydr. Res. 149, 389-410

16. Tvaroska, I. (1984) Carbohydr. Res. 125, 155-160

17. Allinger, N.L., Yuh, Y.H., and Lii, J.H. (1989) J. Am. Chem. Soc. 111, 8551-8566

18. Pearlman, D.A., Case, D.A., Caldwell, J.W., Ross, W.R., Cheatham, T.E. III, DeBolt, S., Ferguson, D., Seibel, G., and Kollman, P. (1995) Comp. Phys. Commun. 91, 1-41

19. Brooks, B.R., Bruccoleri, R.E., Olafson, B.D., States, D.J., Swaminathan, S., and Karplus, M. (1983) J. Comput. Chem. 4, 187-217

20. Allinger, N.L., Rahman, M., and Lii, J.H. (1990) J. Am. Chem. Soc. 112, 8293-8307

21. Woods, R.J., Dwek, R.A., Edge, C.J., and Fraser-Reid, B. (1995) J. Phys. Chem. 99, 3832-3846

22. Basma, M., Sundara, S., Calgan, D., Venali, T., and Woods, R.J. (2001) J. Comput. Chem. 22, 1125-1137

23. Kirschner, K.N., and Woods, R. J. (2001) J. Phys. Chem. A105, 4150-4155

24. Ha, S.N., Giammona, A., Field, M., and Brady, J.W. (1988) Carbohydr. Res. 180, 207-221

25. Palma, R., Himmel, M.E., Liang, G., and Brady, J.W. (2001) in "ACS Symposium Series: Glycosyl Hydrolases in Biomass Conversion" (Himmel, M.E., Baker, J.O., and Saddler, J.N., eds.)”, American Chemical Society, Washington DC, Vol.778, pp.112-130 
26. Kuttel, M., Brady, J.W., and Naidoo, K.J. (2002) J. Comput. Chem. 23, 1236-1243

27. Corzana, F., Motawia, M.S., du Penhoat, C.H., Prez, S., Tschampel, S.M., Woods, R.J., and Engelsen, S.B. (2004) J. Comp. Chem. 25, 573 $-586$

28. Woods, R.J.(1998) Carbohydrate force fields., in "Encyclopedia of Computational Chemistry", (Schleyer, P.V.R., Allinger, N.L., Clark, T., J. Gasteiger, P.A. Kollman, H.F. Schaefer III, P.R. Schreiner, eds.), John Wiley \& Sons, Chichester, Vol.1, pp. 220-233

29. S. Pérez, A. Imberty, S.B. Engelsen, J. Gruza, K. Mazeau, J. Jimenez-Barbero, A. Poveda, J-F. Espinosa, B.P. van Eyck, G. Johnson, French, A.D., Kouwijzer, M.L.C.E., Grootenuis, P.D.J., Bernardi, A., Raimondi, L., Sederowitz, H., Durier, V., Vergoten, G., and Rasmussen, K. (1998) Carbohydr. Res. 314, 141-155

30. Rao, V.S.R., Sundararajan, P.R., Ramakrishnan, C., and Ramachandran, G.N. (1963) in “Conformation of Biopolymers”, Vol. 2, Academic Press, London

31. Dowd, M.K., French, A.D., and Reilly, P.J. (1992) Carbohydr. Res. 233, 15-34

32. Dowd, M.K., Zeng, J., French, A.D., and Reilly, P.J. (1992) Carbohydr. Res. 230, 223-244

33. Dowd, M.K., French, A.D., and Reilly, P.J. (1994) Biopolymers 34, 625-638

34. Rees, D.A., and Scott, W.E. (1971) J. Chem. Soc., Ser.B, 469-479

35. Dowed, M.K., French, A.D., and Reilly, P.J. (1995) J. Carbohydr. Chem. 14, 589-600

36. Imberty, A., Tran, V., and Pérez, S. (1990) J. Comp. Chem. 11, 205-216

37. Yui, T., Kobayashi, H., Kitamura, S., and Imada, K. (1994) Biopolymers 24, 203-208

38. Van Alsenoy, C., French, A.D., Cao, M., Newton, S.Q., and Schäfer, L. (1994) J. Am. Chem. Soc. 116, 9590-9595

39. Schmidt, R.K., Teo, B., and Brady, J.W. (1995) J. Phys. Chem. 99, 11339-11343

40. Naidoo, K.J., and Brady, J.W. (1999) J. Am. Chem. Soc. 121, 2244-2252

41. Ueda, K., and Brady, J.W. (1996) Biopolymers 38, 461-469

42. Ueda, K., Ueda, T., Sato, T., Nakayama, H., and Brady, J.W. (2004) Carbohydr. Res. 339, 1953-1960

43. Ueda, K., and Brady, J.W. (1997) Biopolymers 41, 323-330

44. Brant, D.A., and Christ, M.D. (1990) in "ACS Symposium Series: Computer Modeling of Carbohydrate Molecules" (French, A.D., and Brady, J.W., eds.), Vol. 430, pp.42-68

45. Shimada, J., Takeo, H., Takada, T., Kitamura, S., and Kajiwara, K. (2000) J. Phys. Chem. B 104, 2136-2147

46. Kitamura, S., Isuda, H., Shimada, J., Takada, T., Tahara, T., Okada, S., Mimura, M., and Kajiwara, K. (1997) Carbohydr. Res. 304, 303314

47. Kitamura, S., Minami, T., Nakamura, Y., Isuda, H., Kobayashi, H., Mimura, M., Urakawa, H., Kajiwara, K., and Ohno, S. (1997) J. Mol. Struc. (THEOCHEM) 395-396, 425-435

48. French, A.D., and French, W.A. (1980) in "ACS Symposium Series: Fiber Diffraction Methods” (French, A.D., ed.), Vol. 141, pp.239-250

49. Yui, T., Nabekura, T., and Ogawa, K. (1997) Carbohdr. Res. 304, 341-345

50. Yui, T., Kawano, Y., and Ogawa, K. (2000) J. Carbohydr. Chem. 19, 1075-1081

51. Yui, T., Goto, K., Kawano, Y., and Ogawa, K. (2000) Biosci. Biotechnol. Biochem. 64, 52-60

52. Nyholm, P.G., Mulard, L.A., Miller, C.E., Lew, T., Olin, R., and Glaudemans, C.P.J. (2001) Glycobiology 11, 945-955

53. Rosen, J., Robobi, A., and Nyholm, P.G. (2002) Carbohydr. Res. 337, 1633-1640

54. Rosen, J., Robobi, A., and Nyholm, P.G. (2004) Carbohydr. Res. 339, 961-966

55. Wilberg, K.B., and Murcko, M.A. (1989) J. Am. Chem. Soc. 111, 4821-4828

56. J. Koča (1994) J. Mol. Struc. (THEOCHEM) 308, 12-24

57. J. Koča (1998) Progr. Biophys. Mol. Biol. 70, 137-173

58. Imberty, A., Mikros, E., Koča, J., Mollicone, R., Oril, R., and Pérez, S. (1995) Glycoconjugate J. 12, 331-349

59. Lemieux, R.U., Bock, K., Delbaere, L.T.J., Koto, S., and Rao, V.S. (1980) Can. J. Chem. 58, 651-653

60. Biswas, M., and Rao, V.S.R. (1980) Biopolymers 19, 1555-1565

61. Cioci, G., Rivet, A., Koča, J., and Pérez, S. (2004) Carbohydr. Res. 339, 949-959

62. Rao, V.S.R., Qasba, P.K., Balaji, P.V., and Chandrasekaran, R. (1998) in "Conformation of Carbohydrates", Harwood academic publishers, pp. 131-158

63. Yan, Z-Y., and Bush, C.A. (1990) Biopolymers 29, 799-811

64. Cagas, P., and Bush, C.A. (1992) Biopolymers 32, 277-192

65. Balaji, P.V., Qasba, P.K., and Rao, V.S.R. (1993) Biochemistry 32, 12559-12611

66. Balaji, P.V., Qasba, P.K., and Rao, V.S.R. (1994) Glycobiology 4, 497-515

67. Qasba, P.K., Balaji, P.V., and Rao, V.S.R. (1994) Glycobiology 4, 805-815

68. Balaji, P.V., Qasba, P.K., and Rao, V.S.R. (1997) J. Mol. Struc. (THEOCHEM) 395-396, 333-360

69. Balaji, P.V., Qasba, P.K., and Rao, V.S.R. (1996) Int. J. Biol. Macromol. 18, 101-114

70. Woods, R.J., Pathiaseril, A., Wormald, M.R., Edge, C.J., and Dwek, R.A. (1998) Eur. J. Biochem. 258, 372-386

71. Yui, T., unpublished results

72. Naidoo, K.J., Denysyk, D., and Brady, J.W. (1997) Protein Engineering 10, 1249-1261

73. Naidoo, K.J., and Brady, J.W. (1997) J. Mol. Struc. (THEOCHEM) 395-396, 469-475

74. Levy, S., Schuyler, S.C., Maglothin, R.K., and Staehelin, L.A. (1996) Biipolymers 38, 251-272

75. T. Yui, unpublished results

Received on May 8, 2005, accepted on July 3, 2005 


\section{Profile of the Authors}

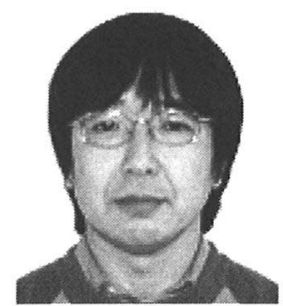

Toshifumi Yui is currently an Associate Professor of the Department of Applied Chemistry, Faculty of Engineering, Miyazaki University (1994-present) and was a Research Associate in the same institute (1989-1994). He graduated from the Department of Agriculture, Osaka Prefecture University, and received his Ph.D. in chemistry from the Department of Chemistry, College of Environmental Science and Forestry, State University of New York for his thesis on the molecular and crystal structure analyses of some polysaccharides. His research career started with a fiber diffraction study of polysaccharide crystals and his interest has mostly been running on molecular modeling and simulation studies of oligo- and polysaccharides, and their crystals to reveal their self ordering behaviors of 3D structure and assembly system. Recently, his research has extended to protein molecular simulation to study the protein-sugar substrate interactions.

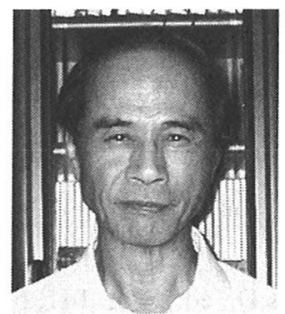

Kozo Ogawa, Education and scientific degrees: 1965 Master course, Department of Agricultural Chemistry, Graduate school of Agriculture, Osaka Prefecture University (Master of Agriculture.). 1974 Doctor of Agriculture from Osaka Prefecture University. Thesis "Solution Behaviors of $\beta$-1,3-D-Glucan"

Workplaces and position:1965-1975 Radiation Center of Osaka Prefecture, Sakai, Osaka, Japan, Researcher. 1975-1976 Department of Chemistry, University of Montreal, Montreal, Canada, Postdoctoral. 1976-1990 Radiation Center of Osaka Prefecture, Sakai, Osaka, Japan, Senior Researcher. 1990 - 1995 Research Institute for Advanced Science and Technology (RIAST), Osaka Prefecture University, Sakai, Osaka, Japan, Associate Professor. 1995-2003 RIAST, Osaka Prefecture University, Sakai, Osaka, Japan, Professor. Retired in 2003. 2003-present RIAST, Osaka Prefecture University, Sakai, Osaka, Japan, Visiting Scientist.

Main fields of interest: Physical chemistry of macromolecules. Polysaccharide conformations in solid states and in solutions. Mechanical properties and gas permeability of polysaccharide membranes. 